\title{
Geïntegreerde stages: een idee voor leersituaties in de huisartsenopleiding
}

\author{
L. Ceulemans, A. Derese, G. Belsack
}

\begin{abstract}
Samenvatting
Curriculumverantwoordelijken voor de huisartsenopleiding in Vlaanderen hebben zich gebogen over een profiel voor de huisarts in de komende decennia. Bepaalde aspecten van dat profiel zoals preventie, gemeenschapsgeoriënteerde zorg, thuiszorg, aandacht voor maatschappelijk zwakkere groepen, palliatieve zorg, gezondheidspromotie, praktijkmanagement en groepsdynamiek, en samenwerking met andere eerstelijnswerkers blijken tijdens de traditionele stages in de huisartsopleiding nauwelijks aan bod te komen. Daarom is gezocht naar nieuwe leersituaties waar de huisarts-in-beroepsopleiding met deze aspecten kennis kan maken. De leerdoelen, randvoorwaarden en outcome van deze 'gë̈ntegreerde stages' werden reeds uitgeschreven, maar de praktische uitwerking van dit project roept nog heel wat vragen op over tijdsinvestering, financiering en selectie van de stageplaatsen. (Ceulemans L, Derese A, Belsack G. Geïntegreerde stages: een idee voor leersituaties in de huisartsenopleiding. Tijdschrift voor Medisch Onderwijs 2001;20(3): 124-129.)
\end{abstract}

\section{Inleiding}

De huisartsopleiding in Vlaanderen bestaat op dit moment uit de oriëntatie huisartsenopleiding in het zevende jaar van de geneeskundeopleiding gevolgd door een tweejarige stage in huisartspraktijken en ziekenhuizen. De huisartsopleiding wordt landelijke gecoördineerd door het Interuniversitair Centrum voor Huisartsenopleiding (ICHO). In 1998 formuleerde het ICHO 'de profielschets van de huisarts van de $21^{\mathrm{e}}$ eeuw'. ${ }^{1}$ Veel aspecten uit deze profielschets komen in de huidige huisartsberoepsopleiding niet of nauwelijks aan bod. Het betreft zaken als preventieve geneeskunde, gemeenschapsgeoriënteerde zorg, geïntegreerde thuiszorg, aandacht voor maatschappelijk zwakkere groepen, palliatieve zorg, thuiszorg, gezondheidsvoorlichting en -opvoeding, praktijkmanagement en groepsdynamiek. Besloten werd om stageplaatsen te zoeken waar de huisarts-in-beroepsopleiding (hibo) met deze aspecten vertrouwd kan raken. Het idee was om deze stages te integreren in de opleiding die de hibo krijgt in de huisartspraktijk waar hij of zij voltijds samenwerkt met de praktijkopleider. Om deze reden werd gekozen voor de naam geïntegreerde stages. In dit artikel wordt de eerste aanzet tot de ontwikkeling van deze stages beschreven.

\section{Leerdoelen van de geïntegreerde stages}

De leerdoelen van de geïntegreerde stages hebben betrekking op kennis, vaardigheden en attitudes. Als het gaat over kennis, denken we aan de werkomgeving, infrastructuur, dagindeling, medewerkers, apparatuur en communicatiemiddelen. Ook moet de hibo zicht krijgen op de clientèle van de betrokken hulpverlener, de aard van de voorkomende problemen, de behandelingsmogelijkheden en de overeenkomsten en verschillen met de huisartspraktijk. Het is belangrijk dat er naast de stagemogelijkheden ook geschikte literatuur beschikbaar is over de betrok- 
ken vakgebieden. Er moet voldoende gelegenheid zijn om specifieke vaardigheden van de betreffende vorm van hulpverlening op een didactisch verantwoorde manier te leren. Met betrekking tot attitudes is de confrontatie met verschillende hulpverleningsvisies en perspectieven van belang. Bewustwording van de eigen opvattingen en die van anderen over hulpverlenen en samenwerken in de gezondheidszorg en het contact met patiënt of cliënt moet bevorderd worden. Dat geldt ook voor de opvattingen en gedragingen over door- en terugverwijzingen en onderlinge verwachtingspatronen.

Voor elk van de stageplaatsen zullen deze algemene doelstellingen specifiek uitgewerkt moeten worden met verwijzing naar de aspecten van het eerder genoemde toekomstprofiel waaraan zij appelleren. Voor een aantal mogelijke stageplaatsen is dat inmiddels al gebeurd. ${ }^{2-6}$

\section{Mogelijke geïntegreerde stageplaatsen}

Momenteel verkeert de ontwikkeling van de geïntegreerde stages nog in een ontwerpfase. Het ICHO heeft een lijst van verschillende mogelijkheden opgesteld. Hieronder volgt een korte beschrijving van elk van die mogelijkheden. Het is een voorlopige lijst, die bedoeld is om discussie te bevorderen en commentaar uit te lokken.

Raadpleging voor het jonge kind: is een door de overheid gesubsidieerde dienst die gratis raadplegingen organiseert voor zuigelingen en jonge kinderen. Deze raadplegingen worden gehouden door een huisarts met bijkomende bekwaming in de jeugdgezondheidszorg of een kinderarts, samen met een sociaal verpleegkundige. Deze laatste legt ook huisbezoeken af. Veel aandacht gaat naar adviezen over gezonde voeding en leefgewoonten, preventie van wiegendood en het toedienen van vaccinaties. De zuigeling en het jonge kind worden ook volledig klinisch onderzocht en de psychomotorische ontwikkeling wordt nauwgezet gevolgd.

Centra voor LeerlingenBegeleiding: aan alle scholen is een C.L.B.-centrum verbonden. Een medewerker volgt de klasseraden, zij doen klassiek testonderzoek naar schoolrijpheid, motivatie, interesse en begaafdheid. De leerlingen worden ook medisch onderzocht. Indien nodig wordt overgegaan tot individuele testen, begeleiding en/of verwijzing.

Comité voor Bijzondere Jeugdzorg en Jeugdrechtbank: het Comité heeft een belangrijke preventieve taak en moet bijstand en hulp organiseren in problematische opvoedingssituaties. De jeugdrechtbank kan dwingend optreden en beschikt over een aantal mogelijkheden om kinderen en jongeren tijdelijk of definitief uit huis te plaatsen in instellingen of gezinnen. Ze is voor minderjarigen ook bevoegd in strafzaken.

Consultatiebureau's en Centra voor Levensen Gezinsvragen: een multidisciplinair team staat ter beschikking van de hulpvrager voor medische, juridische en relationele problemen.

Centra voor hulp aan slachtoffers: deze centra geven emotionele en juridische ondersteuning aan slachtoffers van misdrijven (mishandeling, aanranding, verkrachting, et cetera).

Diensten voor Geestelijke Gezondheidszorg: binnen een dienst voor geestelijke gezondheidszorg verstrekt een gespecialiseerd multidisciplinair team van psychiaters, psychologen, en maatschappelijk werkers ambulante psychische hulp en begeleiding. 
Diensten voor Thuisbegeleiding in de Bijzondere Jeugdzorg: thuisbegeleiding wordt opgezet voor gezinnen waarvoor een intensief begeleidingsplan hulp kan bieden bij problematische opvoedingssituaties. De begeleiding wordt thuis gegeven, rekening houdend met de totale gezinscontext. Begeleiding kan gevraagd worden door het centrum voor bijzonder jeugdzorg of de jeugdrechtbank.

Diensten voor Vroeg- en Thuisbegeleiding van personen met een handicap: voor gezinnen met kinderen met een vertraagde ontwikkeling of met een mentale, motorische of meervoudige handicap.

Adviserend arts van de mutualiteit: bij langdurige arbeidsongeschiktheid door ziekte of ongeval moet beoordeeld worden of de ziekte-uitkering (het eerste jaar) of de invaliditeitsuitkering (vanaf het tweede jaar) nog verantwoord zijn. Ook de terugbetaling van hulpmiddelen, prothesen en orthesen en van sommige duurdere medicaties zoals ace-inhibitoren en H2antagonisten wordt hier gecontroleerd.

Kinesitherapie (fysiotherapie): in Vlaanderen moet de patiënt in bezit zijn van een voorschrift van de huisarts of specialist om terugbetaling te krijgen van een kinesitherapeutische behandeling. Omdat dit zeer frequent voorkomt in de eerstelijnsgezondheidszorg en omdat huisartsen dikwijls geen goede kijk hebben op deze behandeling, lijkt ons dit een zeer interessante stageplaats.

Vertrouwenscentra Kindermishandeling: Iedereen die vanuit zijn beroep of vanuit zijn omgeving een situatie van geweld tegen kinderen kent of vermoedt, kan contact opnemen met een centrum. Een teamlid bekijkt samen met de melder de verwachtingen en wat het centrum kan bieden: advies, contact met het kind of de jongere. De bedoeling is de geweldsituatie bespreekbaar te maken en via hulp verandering mogelijk te maken. De centra proberen dit te bereiken zonder tussenkomst van justitie. Er bestaan centra in alle provincies.

Openbaar Centrum voor Maatschappelijk Welzijn (OCMW): in elke gemeente is een dergelijke dienst aanwezig. Deze dienst verleent zeer verscheiden hulpverlening: preventief, curatief, van materiele en/of psychologische aard. Het OCMW kan een aantal diensten en voorzieningen uitbouwen: gezins- en bejaardenhulp, levering van warme maaltijden, financiële hulpverlening, rusthuizen, sociale woningbouw, kinderdagverblijven.

Thuisverpleging: verpleegkundigen geven alle verpleegkundige zorg van welke aard ook. De verzorging kan meerdere malen per dag gebeuren. Er is (nog) geen nachtdienst. Voor elke verzorging is een voorschrift van de arts vereist. Er is terugbetaling via het ziekenfonds. Belangrijke aspecten zijn: samenwerking tussen huisarts en verpleegkundige, zorgplan, mantelzorg en diverse technische vaardigheden zoals prikken van een 'porth a cat' en aanleggen en verzorgen van sondes en infusen.

Palliatieve thuiszorg: de overheid heeft palliatieve netwerken opgericht met een thuiszorgequipe die bestaat uit speciaal geschoolde verpleegkundigen en artsen. De taak van deze equipes bestaat erin de thuisgezondheidswerkers met raad en daad bij te staan zonder dat hun de zorg wordt ontnomen. Daarnaast hebben deze netwerken een belangrijke taak in voorlichting aan de bevolking en in bijscholing van de zorgverstrekkers in de eerste lijn (thuis en in rust- en verzorgingstehuizen) 
en in de ziekenhuizen. Op die manier probeert men het voor meer mensen mogelijk te maken om in optimale omstandigheden thuis te kunnen sterven.

Centrum voor Aangepast Rijden van Automobilisten (CARA): meer en meer worden artsen betrokken bij de beoordeling van de rijvaardigheid van hun patiënten. Indien de arts tijdens zijn onderzoek een vermindering van de functionele vaardigheden vaststelt, kan hij de patiënt doorverwijzen naar het CARA. Het team bestaat uit een arts, een psycholoog en een aanpasdeskundige. Zij doen een psychotechnisch onderzoek en nemen een praktische rijproef af op de openbare weg. De adviezen worden meegedeeld aan de betrokkene en zijn of haar behandelend arts.

Zelfhulpgroepen: steeds meer hulpverleners erkennen het belang en de waarde van zelfhulp als belangrijke aanvulling op de eigen professionele hulpverlening. Samenwerking en doorverwijzen naar zelfhulpgroepen zijn een uiting van een patiëntgerichte aanpak.

Telefonische hulpverlening: zoals anti-gifcentrum, teleonthaal, aids-telefoon. Telefonische communicatie met patiënten is belangrijk in onze multimediamaatschappij.

Apotheker: in Vlaanderen mag de huisarts al lang geen eigen apotheek meer hebben. Een dergelijke stage kan leerzaam zijn voor de hibo met het oog op het correct voorschrijven, praktische aspecten van magistrale bereidingen en bewustwording van de kosten.

Podoloog: een zeer frequent 'zeer' in de huisartsenpraktijk zijn de voetproblemen. Bijvoorbeeld het belang van een goede voetverzorging bij patiënten met diabetes.
Diëtist: in Vlaanderen wordt de huisarts frequent geconsulteerd voor gewichts- en voedingsproblemen. Dit heeft te maken met het feit dat verzorging door diëtisten niet in het ziekenfondspakket is opgenomen. De huisarts kan eet- en gewichtsproblemen vroegtijdig op het spoor komen, maar heeft een gebrekkige opleiding in deze materie. Een goede samenwerking met een diëtist kan dan ook de kwaliteit van het huisartsgeneeskundig handelen enorm doen toenemen.

Laboratorium voor klinische biologie: dit is een zeer belangrijk aspect van het huisartsgeneeskundig handelen zowel in frequentie als in kosten als in uitdaging voor het besliskundig verantwoord aanvragen van testen. 6

Arbeidsgeneeskundige dienst: werkomstandigheden kunnen ongeval en ziekte in de hand werken. Arbeidsartsen hebben een belangrijke preventieve en adviserende taak. Huisartsen hebben vaak geen goede kijk op deze werkomstandigheden.

Gerechtelijke geneeskunde: dit is in België nog steeds geen erkend specialisme. In principe kan dus elke arts door de gerechtelijke instanties verzocht worden deze taak op zich te nemen.

Op dit moment zijn er met nog geen van de betrokken instellingen of diensten concrete afspraken gemaakt. Het ontwerp is al wel goedgekeurd door de academische huisartsencentra en het zogenaamde hibo-forum, dat de belangen van hibo's behartigt.

\section{Ontwikkeling en implementatie}

Na overleg in de Permanente Onderwijscommissie van het ICHO, werd beslist om het concept geïntegreerde stages voorlopig aan te bieden als een keuzemogelijkheid 
zonder een formeel examen. De hibo zou bij voorkeur een patiënt uit de opleidingspraktijk vergezellen tijdens de contacten die deze patiënt heeft met een van de hierboven vermelde diensten. Het tijdstip en de duur van de geïntegreerde stages zou dus bepaald worden door de momenten waarop de patiënt van deze voorzieningen gebruikmaakt.

Stilaan groeit echter de overtuiging binnen het ICHO dat de hibo twee halve dagen per week vrij moet krijgen van de praktijkopleider. Een van deze halve dagen is bedoeld voor de georganiseerde opleidingsmomenten. De andere zou dan beschikbaar zijn voor geïntegreerde stages en zelfstudie. Het zoeken van geschikte stageplaatsen moet bij voorkeur gebeuren door de praktijkopleiders, de coördinatoren en het staflid van het ICHO die binnen een bepaalde regio actief zijn. Informatie hierover kan worden uitgewisseld op de regionale samenkomsten van praktijkopleiders met de coördinator (planningsvergadering) en van het regionaal staflid met de coördinatoren van een bepaalde regio (regionaal overleg en planningsgroep).

De uiteindelijke invulling van de stages door de hibo moet gaan plaatsvinden op basis van de individuele leeragenda. De voortgangsgesprekken en de evaluatiegesprekken die coördinator en praktijkopleider met hun hibo voeren, helpen om hierbij de juiste keuzes te maken.

Op het einde van de opleiding kan van de hibo gevraagd worden een portfolio voor te leggen (bijvoorbeeld op het mondeling examen) van alle initiatieven die hij of zij ondernomen heeft om aan het toekomstprofiel van de huisarts van de $21^{\text {ste }}$ eeuw te voldoen.

Het project wordt momenteel voorgesteld op de verschillende stafvergaderingen van het ICHO. Daarna kan het verder worden uitgewerkt samen met coördinatoren, praktijkopleiders en hibo's. Informatie over het project zal verschijnen op de website van het ICHO (www.icho.be). Het eerste jaar zal worden gezien als een proefperiode.

Aan de discussie over het beschrevene hebben meegedaan: de leden van de stafgroep curriculum van het ICHO: Jan Michels, Roy Remmen, Marc Dusauchoit, Danielle Grouwels, Irene Ottenhof, Emmanuel Samyn, Rik Huybrechts.

\section{Literatuur}

1. Derese A, Belsack G, Michels J, Leroy D. Profielomschijving van de huisarts van de 21 ste eeuw [ICHO-document]. Leuven: ICHO; mei 1998.

2. Michels J. Welke zou de inhoud kunnen zijn van een stage door hibo's in Medisch Schooltoezicht en Kind en Gezin [Intern ICHO-document]. Leuven: ICHO; januari 1999.

3. Ottenhof I. Leerdoelen stage geestelijke gezondheidszorg [Intern ICHO-document]. Leuven: ICHO; april 1999.

4. Grouwels D. Leerdoelen en omkadering van geïntegreerde stage vertrouwensartscentrum [Intern ICHO document]. Leuven: ICHO; juni 1999.

5. Grouwels D. Geïntegreerde stage thuisgezondheidszorg [Intern ICHO-document]. Leuven: ICHO; juni 1999.

6. Samyn E. Mogelijke geïntegreerde stage: laboratorium klinische biologie [Opbouwtekst]. Leuven: ICHO: 1999.

De auteurs:

Dr. L. Ceulemans is huisarts-praktijkopleider te SintKatelijne-Waver en coördinator van de Afdeling Onderzoek van de Wetenschappelijke Vereniging van Vlaamse Huisartsen. Ten tijde van het schrijven van dit artikel was hij lid van de staf curriculum en van de staf praktijkopleiding van het ICHO.

Prof. dr. A. Derese is huisarts in het wijkgezondheidscentrum Botermarkt te Ledeberg en docent bij het ICHO aan de RUGent.

Dr. G. Belsack is huisarts te Ternat en coördinator, tevens staflid van de staf seminaries en de staf curriculum van het ICHO.

Correspondentieadres:

Dr. Lucas Ceulemans, huisarts, Voorland 1, 2860 SintKatelijne-Waver, België.

e-mail:lucas.ceulemans@village.uunet.be 


\section{Summary}

Those responsible for the curriculum of the vocational training programme for general practitioners in Flanders have recently addressed the profile of the GP in the coming decades. Various aspects of this profile are currently receiving only limited attention during the traditional traineeships in general practice. The aspects that are being neglected are: prevention, community care, home care, care for the socially disadvantaged, palliative care, health education, practice management and group dynamics, and co-operation with other workers in primary health care. The inclusion of new educational settings in the training programme for general practitioners has been considered as a means of resolving these shortcomings. The learning objectives, prerequisites, and outcomes of the proposed so-called 'integrated traineeships' have been described. The implementation of the proposals raises a multitude of questions regarding time investment, funding, and selection of suitable settings for the traineeships (Ceulemans L, Derese A, Belsack G. Integrated traineeships: a proposal for the introduction of new settings into the vocational training programme for general practice. Dutch Journal of Medical Education 2001;20(3): 124-129.) 